\title{
Classification and Beauty Styles Analysis according to Images of Silver Generation Women Celebrities
}

\author{
Yun-Kyoung Oh \\ Department of Cosmetology, Changshin University, Chamgwon-si, Gyeongsangnam-do, Korea
}

Corresponding author: Yun-Kyoung Oh, Department of Cosmetology, Changshin University, 262 Palyongro, MasanHoewongu, Changwon, Gyeongsangnam-do 51352, Korea

Tel.: +82552501212

Fax: +82552501215

Email: yk212@cs.ac.kr

Received November 5, 2018

Revised January 11, 2019

Accepted February 7, 2019

Published March 30, 2019

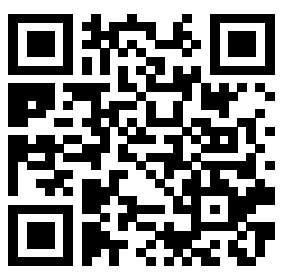

\begin{abstract}
Purpose: This study classified silver generation female celebrities according to images of the younger generation in order to analyze beauty, style, and image differences according to generation type. The study data can be used to inform fashion and beauty product development through improving our understanding of silver generation women's representative style, which is emerging as a new consumer segment. Methods: 50 images of silver age female celebrities who ranged from 55 to 65 years of age. A total of 20 adjective pairs were extracted with reference to a previous study of image evaluation using a 7-point semantic differential scale. The rating of female celebrities according to the adjectives was 'like-dislike'. Data collection was conducted from June 1, 2018, to June 15, 2018. Results: The results of this study are summarized as follows. First, there were four factors constituting images of silver generation female celebrities-affinity, attractiveness, activity, and individuality-and accounted for $65.28 \%$ of the total variance. Second, the silver generation female celebrities were placed into one of five groups named 'soft style', 'calm style', 'conservative style', 'refined style', and 'social style'. Third, as a result of examining the image difference according to type, 'soft style' had the highest affinity, 'calm style' and 'refined style' were rated as more attractive, and 'sociable style' had the highest activity and individuality rating. Fourth, the images of silver generation female celebrities deemed the most attractive and unique by those in their twenties were those of Hwa Jung Choi and Mi Sook Kim. Conclusion: The most important dimension of the silver generation female celebrity image was the affinity factor, which could be applied to the pursuit of style presentation and image implementation with reference to communitydefined characteristics of beauty and style. Accordingly, this study found that a friendly image was characterized by a 'soft style'; an attractive image by the external features of a 'calm style' and/or 'refined style'; and an active image with individuality was characterized by a 'social style'.
\end{abstract}

Keywords: Silver generation, Celebrities, Image, Classification, Beauty style

\section{Introduction}

급속한 경제성장과 현대의학의 발전은 인간의 삶의 질을 향상 시키고 평균수명을 연장시킴에 따라 노인인구가 급격히 증가하 였으며 전 세계적으로 인구의 고령화 현상이 두드러지고 있다. 우리나라의 노인인구도 2018년 14.3\%에 달할 것으로 예상되어 $\mathrm{UN}$ 이 정한 고령사회에 진입하게 되며 2026년에는 65 세 이상의 인구 비율이 $20 \%$ 에 달하는 초 고령사회가 될 것으로 전망된다
(Kim, 2014), 실버세대라는 용어는 노년층을 달리 이르는 말로 학문적으로 그 개념이 정립되어 있는 것은 아니나 노인의 흰머리 를 미화시켜 표현한 어휘로 1990년대부터 보편적으로 사용되어 왔다. 그러나 현대를 살아가는 실버세대 여성들은 과거의 노인 (老人)들과 달리 안정된 경제력과 높은 지적, 문화적 수준을 갖 추고 있으며 새로운 소비세력, 소비 트렌드를 좌우하는 소비주체 로 분류되고 있다(Im \& O, 2010). 또한 실버세대의 다양한 사회 활동과 대인관계는 외모에 대한 욕구를 증가시키고 미용에 대한 
관심과 적극적인 외모관리행동으로 이어지고 있다. 그럼에도 불 구하고 젊은 세대가 인식하고 있는 실버세대 여성들은 획일화된 이미지로 표현되는 경우가 많아 현재 우리사회가 실버세대의 내 적, 외적 가치변화에 빠르게 대응하지 못하고 있는 것이 아닌지 우려가 된다. 따라서 세대 간의 보편적인 감성을 바탕으로, 현재 실버세대가 표현할 수 있는 이미지와 미용스타일을 구체적으로 파악할 필요가 있다.

실버세대의 범위는 사회, 문화적 배경과 전통에 영향을 받아 나라마다 다르게 해석되는데, 미국은 인구조사국에서 55 세를 노 인의 경계점으로 보고 있으며 우리나라의 경우 보편적인 퇴직연 령이 55 세이다(Jo \& Kim, 2009). 이 시기의 여성들은 폐경기를 지나게 되면서 신체적, 심리적 변화와 노화현상이 두드러지고 자 녀의 결혼과 독립으로 인한 가정생활과 사회활동의 극심한 변화 를 겪게 된다. 따라서 본 연구에서는 55 세를 기준으로 실버세대 를 구분하고자 한다. 현재 실버세대를 대상으로 한 미용 관련 연 구들은 미용 제품이나 서비스 구매실태(Jo \& Kim, 2009; Kang \& Park, 2007), 미용관리 행동 및 심리(Kim, 2011; Kim et al., 2013; Park, 2015)와 관련된 연구가 대부분으로 실버세대 의 이미지와 스타일을 분석한 연구는 매우 부족한 실정이다.

따라서 본 연구는 실버세대 여성유명인을 대상으로 젊은 세대 가 느끼는 이미지에 따라 유형화하고 유형에 따른 미용스타일과 이미지 차이를 분석하고자 한다. 미디어에 나타나는 유명인은 다 양한 이미지로 대중문화에 영향을 미치며 유행을 선도하고 있고 일반인의 패션과 미용스타일 동조행동을 유발시킬 수 있어 유형 화의 적합성 및 활용도가 높을 것으로 예상된다. 본 연구는 새로 운 소비계층으로 부각되고 있는 실버세대의 대표적인 스타일을
구분함으로써 실버세대 여성에 대한 이해를 돕고 패션과 미용 상 품 개발 및 이미지메이킹의 기초자료로 활용될 수 있을 것으로 사료된다.

\section{Methods}

\section{1. 자극물의 구성}

대표적인 실버세대 여성유명인을 선정하기 위하여 2018년 5 월 16 일부터 5 월 20 일까지 중앙일보, 조선일보의 홈페이지 인물 검색에서 55 세 이상 65 세 이하의 여성유명인을 조사하였고 이 중 인지도를 고려하여 50 명의 유명인을 선정하였다.

이미지 평가 자극물을 구성하기 위하여 포털사이트 및 연예기 사 등에서 해당 유명인의 인터뷰, 프로필 사진을 수집하였으며 미용관련 교수 및 전문가 3 인으로 구성된 집단의 평가에 따라 대 표자극물을 추출하였다. 사진자극물은 이미지 편중을 피하고자 4-6장의 사진을 배경을 제외하고 이미지맵의 형태로 평가자에 게 제시하였다.

\section{2. 자극물에 대한 이미지평가}

실버세대 여성유명인의 이미지 평가를 위하여 일대일 대인면 접에 의한 설문조사를 실시하였으며 이미지 평가에 적합한 어휘 는 선행연구(Kim \& Lee, 2009; Oh \& Lee, 2006)를 참고로 총 20 개의 형용사쌍이 추출하였고 7 점 의미미분척도(양극)로 구성 하였다. 여성유명인의 선호도 평가는 '좋아하는-좋아하지 않는' 문항을 사용하였다. 자료 수집은 2018년 6월 1일부터 6월 15일

Table 1. Image factors of silver generation women celebrities

\begin{tabular}{|c|c|c|c|c|}
\hline Factors & Adjective & Factor loading & Variance explained (\%) & Cumulative variance (\%) \\
\hline \multirow{6}{*}{ Affinity } & Good impression-Bad impression & 0.803 & \multirow{6}{*}{20.58} & \multirow{6}{*}{20.58} \\
\hline & Docile-Dread & 0.800 & & \\
\hline & Warm-Cool & 0.776 & & \\
\hline & Soft-Hard & 0.752 & & \\
\hline & Bright-Dark & 0.638 & & \\
\hline & Modest-Gorgeous & 0.591 & & \\
\hline \multirow{5}{*}{ Attractiveness } & Chic-Unchic & 0.902 & \multirow{5}{*}{17.99} & \multirow{5}{*}{38.57} \\
\hline & Elegant-Unelegant & 0.863 & & \\
\hline & Urban-Countrified & 0.809 & & \\
\hline & Intellectual-Non-intellectual & 0.777 & & \\
\hline & Attractive-Unattractive & 0.654 & & \\
\hline \multirow{5}{*}{ Activity } & Dignified-Undignified & 0.810 & \multirow{5}{*}{14.16} & \multirow{5}{*}{52.73} \\
\hline & Adaptable-Unadaptable & 0.663 & & \\
\hline & Charismatic-Uncharismatic & 0.643 & & \\
\hline & Strong-Weak & 0.641 & & \\
\hline & Sociable-Unsociable & 0.533 & & \\
\hline \multirow{3}{*}{ Individuality } & Excited-Calm & 0.734 & \multirow{3}{*}{12.55} & \multirow{3}{*}{65.28} \\
\hline & Lively-Quiet & 0.695 & & \\
\hline & $\begin{array}{l}\text { Open minded-Conservative } \\
\text { Individual-Non individual }\end{array}$ & $\begin{array}{l}0.695 \\
0.540 \\
\end{array}$ & & \\
\hline
\end{tabular}

Reliability: Cronbach's $\alpha$ is 0.75 . 
까지 이루어졌으며 20대 300명을 대상으로 이미지 평가를 실시 하였고 피로도를 고려하여 한 명이 10 개의 자극물을 평가하였 다. 수집된 자료 중 불성실한 자료를 제외한 255 명의 자료가 최 종 분석에 사용되었다.

\section{3. 자료 분석방법}

이 연구의 분석은 통계분석과 내용분석을 사용하였다. SPSS 20.0 프로그램(IBM, USA)을 활용하여 이미지의 구성요인은 요 인분석, 여성유명인의 분류는 $\mathrm{K}$-평균군집분석을 사용하였고 이 미지 차이는 분산분석을 실시하였다. 유형별 미용스타일은 얼굴 (얼굴형, 이마, 눈썹, 눈, 코, 입)과 헤어스타일(길이, 형태)의 외 형적 특징을 중심으로 내용분석을 실시하였다.

\section{4. 연구문제}

연구문제 1. 실버세대 여성유명인의 이미지 구성요인을 알아본다. 연구문제 2. 실버세대 여성유명인의 이미지에 따른 유형화 및 미용 스타일을 분석한다.

연구문제 3. 실버세대 여성유명인의 유형에 따른 이미지 차이를 알 아본다.

연구문제 4. 실버세대 여성유명인의 선호도 및 이미지 순위를 알아 본다.

\section{Results and Discussion}

\section{1. 실버세대 여성유명인의 이미지 구성요인}

실버세대 여성유명인의 이미지 구성요인을 알아보기 위해 주 성분법을 사용하여 Varimax 직교회전을 통한 요인분석을 실시 하였다. 그 결과 요인 수는 고유값 1.0 이상에서 4 개의 요인으로 추출되었고 전체 변량의 $65.28 \%$ 를 설명하는 것으로 나타났다. 항목에 대한 신뢰도는 Cronbach's $\alpha$ 이 0.75로 신뢰할 수 있으 며, 요인 분석한 결과는 Table 1 과 같다.

요인1은 '인상 좋은-인상 나쁜', '온순한-무서운', '따뜻한-차 가운', '부드러운-딱딱한', '밝은-어두운', '수수한-화려한' 등 6 개의 이미지 어휘로 구성되어 친화성요인이라 하였으며, 전체변 량의 $20.58 \%$ 를 차지하였다. 요인 2 는 '세련된-촌스러운', '우아 한-우아하지 않은', '도시적인-전원적인', '지적인-지적이지 않 은', '매력적인-매력적이 아닌' 등 5 개의 이미지 어휘로 구성되 어 매력성 요인이라 하였으며 전체변량의 $17.99 \%$ 를 차지하였 다. 요인 3은 '당당한-당당하지 않은', '시원한-답답한', '카리스 마 있는-카리스마 없는', '강한-약한', '사교적인-비사교적인' 등 5 개의 이미지 어휘로 구성되어 활동성요인이라 하였으며 전 체변량의 $14.16 \%$ 를 차지하였다. 요인 4 는 '들뜬-차분한', '발랄 한-점잖은', '개방적인-보수적인', '개성 있는-개성 없는' 등 4개 의 이미지 어휘로 구성되어 개성요인이라 하였으며 전체변량의 $12.55 \%$ 를 차지하였다.

각 요인을 구성하고 있는 이미지 어휘에 대해 선행연구와 비교 하면, 요인 1의 친화성요인은 Oh \& Lee (2006)의 친근함 요인 과 부합되고, Kim \& Kang (2003)의 온유성 요인과 유사하며, Lee \& Park (1998)의 친화 요인과 부합된다. 요인 2 의 매력성 요인은 Kim \& Lee (2003)의 매력성 요인과 유사하다. 요인 3의 활동성 요인은 Oh \& Lee (2006)의 외향성 요인과 부합되며 요

Table 2. Classification of silver generation women celebrities

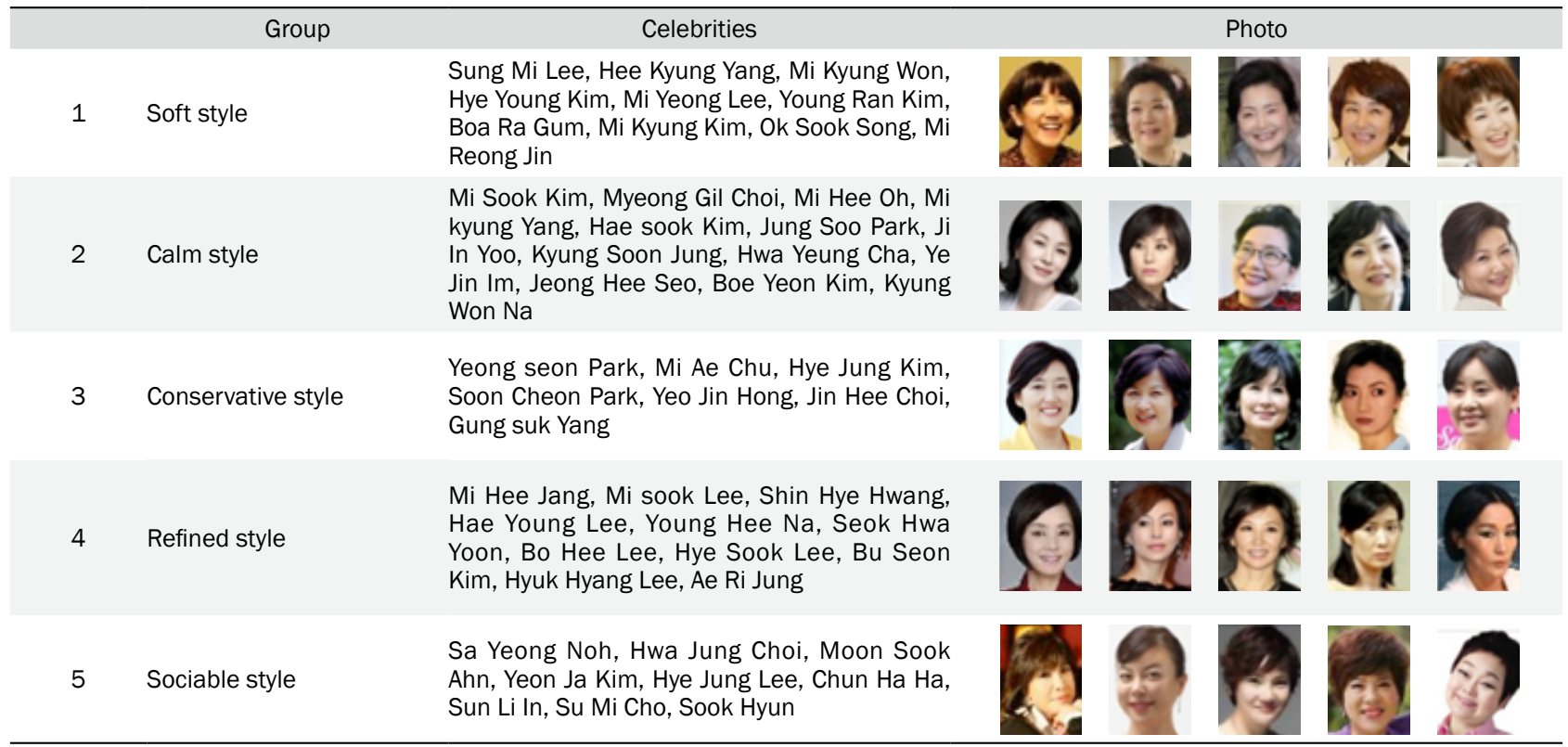


인 4 의 개성요인은 Kim \& Lee (2003)의 개성 요인과 부합된다.

\section{2. 실버세대 여성유명인의 이미지에 따른 유형화 및 미용스타일 분석}

실버세대 여성유명인의 이미지를 유형화하기 위해 $\mathrm{K}$-평균 군 집 분석을 실시하였으며, 5 개의 군집으로 분류되었다(Table 2). 군집분석 결과, 군집 1 은 이성미, 양희경, 원미경 등 10 명으로 구성되었다. 이 군집의 미용스타일을 살펴보면, 대체적으로 타 원형의 얼굴 형태로 볼살이 도톰한 편이며, 이마는 반듯하고 넓 은 편이다. 눈썹은 부드러운 아치형이고, 눈의 형태는 반달형이 거나 큰 편이며 코는 약간 긴 편이고, 입술은 다소 아랫입술이 두 꺼운 편이다. 헤어스타일은 이마를 드러내는 형태로 짧은 스타일 이 많고, 긴 경우에는 올리거나 하나로 묶어주는 스타일을 연출 한다. 이와 같은 특성을 바탕으로 군집 1 은 '부드러운 스타일'로 명명하였다. 군집 2 는 김미숙, 최명길, 박정수, 오미희 등 13 명 으로 구성되었다. 이 군집의 미용스타일을 살펴보면, 역삼각형과 마름모 형태가 많으며 턱선이 갸름하거나 광대가 도드라지는 형 태가 많다. 이마는 반듯하며 넓은 편이고, 눈썹은 자연스러운 둥 근형이다. 눈은 크지는 않지만 또렷한 눈매가 많이 나타난다. 콧 대는 날카롭고 콧방울은 작은 편이며, 입은 작고 입술의 두께는 보통인 형태가 많다. 헤어스타일은 중간 길이의 단발 형태가 주 류를 이룬다. 이와 같은 특성을 바탕으로 군집 2 는 '차분한 스타 일'로 명명하였다. 군집 3 은 박영선, 추미애, 김혜정 등 7 명으로 구성되었다. 이 군집의 미용스타일을 살펴보면, 타원형과 턱 선 이 각진 형태로 이마는 좁은 형태가 많으며, 눈썹은 각 지거나 사 선형으로 강한 편이다. 콧대는 다소 낮은 편이며 입은 작고 얇은 입술이 많은 편이다. 헤어스타일은 단발형태와 올린 머리 형태가 많다. 이와 같은 특성을 바탕으로 '보수적인 스타일'로 명명하였 다. 군집 4 는 장미희, 이미숙, 황신혜 등 11 명으로 구성되었다. 이 군집의 특성을 살펴보면, 타원형과 긴 형이 많으며, 턱 선은 완만한 편이고 이마는 도톰하고 넓은 편이다. 미간은 넓고 둥근 형 눈썹의 형태이며, 눈은 큰 형태가 많고 반달 형태이다. 코 선 이 또렷하고 긴 형태가 많다. 헤어스타일은 중간 길이와 올린 머 리 스타일이 많이 나타난다. 이와 같은 특성을 바탕으로 군집 4
는 '세련된 스타일'로 명명하였다. 군집 5 는 노사연, 최하정, 안 문숙 등 9 명으로 구성되었다. 이 군집은 사각형과 타원형의 형태 로 턱 선이 둔한 편이며, 이마는 다소 넓은 편이다. 눈썹은 각진 형이나 사선형이다. 눈은 큰 형태가 많으며, 콧대는 높고 콧방울 이 큰 편이다. 입은 다소 크며 입술의 두께는 얇은 형태가 많이 나타난다. 헤어스타일은 이마를 가리는 형태가 많으며, 짧은 커 트와 긴 혜어스타일로 풀어 내린 형태이다. 이와 같은 특성을 바 탕으로 '사교적인 스타일'로 명명하였다.

실버세대의 이미지 유형과 관련한 선행연구와 비교하면, $\mathrm{Sim}$ (2006)의 연구에서 중년여성의 자아이미지는 지적 이미지, 사교 적 이미지, 세련된 이미지, 여성스런 이미지, 대담한 이미지로 5 개의 유형으로 분류되어 이 연구의 유형과 유사함을 알 수 있다. Wee \& Sohn (2001)의 연구에서는 55 세 이상의 여성이 추구하 는 이미지를 품위 있는 이미지, 젊어 보이는 이미지, 세련된 이 미지, 고상한 이미지, 우아한 이미지 등 5 개의 유형으로 분류되 었는데 품위 있는 이미지, 세련된 이미지, 고상한 이미지, 우아 한 이미지가 이 연구의 유형과 유사하며, Oh \& Lee (2006)의 연구에서는 국내여자연예인을 대상으로 이미지 유형을 나누었는 데 엘레건트 스타일, 내추럴 스타일, 터프 스타일, 로맨틱 스타 일, 섹시 스타일 등 5 개로 분류되어 이 연구와는 다소 차이가 있 었다. 이는 연구 대상이 인지도가 높은 연예인으로 대부분 젊은 연령이라 유형의 명명에 차이가 나타난 것으로 생각된다.

\section{3. 실버세대 여성유명인 유형에 따른 이미지 차이}

실버세대 여성유명인의 유형에 따른 이미지 차이를 알아보 기 위해 이미지 구성요인 및 이미지 어휘에 대하여 분산분석과 Scheffé 검증을 실시하였다. 그 결과는 Table 3 , Table 4 와 같 다. 실버세대 여성유명인의 이미지 구성 요인에 대한 유형 간의 평가 차이를 살펴본 결과 모든 구성 요인에서 유의한 차이가 나 타났다. 친화성요인에서는 '부드러운 스타일'이 가장 높게 평가되 었고, 그 다음은 '차분한 스타일'이었으며 '세련된 스타일'과 '보수 적인 스타일'은 낮게 평가되었다. 매력성 요인에서는 '차분한 스 타일'과 '세련된 스타일'이 높았으며, '부드러운 스타일'과 '사교적 인 스타일'이 매력성이 낮은 것으로 나타났다. 활동성요인에서는

Table 3. Difference in factors according to style group

\begin{tabular}{|c|c|c|c|c|c|c|}
\hline Factors & Soft style & Calm style & Conservative style & Refined style & Sociable style & $F$-value \\
\hline \multirow{2}{*}{ Affinity } & 5.0 & 4.5 & 3.6 & 3.4 & 4.3 & \multirow{2}{*}{$187.00^{* * *}$} \\
\hline & a & $\mathrm{b}$ & $d$ & $d$ & C & \\
\hline \multirow{2}{*}{ Attractiveness } & 4.0 & 5.1 & 4.5 & 5.4 & 4.1 & \multirow{2}{*}{$154.23^{* * \star}$} \\
\hline & C & $\mathrm{a}$ & $b$ & a & $\mathrm{C}$ & \\
\hline \multirow{2}{*}{ Activity } & 4.5 & 4.7 & 4.7 & 5.4 & 5.5 & \multirow{2}{*}{$109.30^{* * \star}$} \\
\hline & $c$ & $c$ & c & $\mathrm{b}$ & $a$ & \\
\hline \multirow{2}{*}{ Individuality } & 4.0 & 3.7 & 3.2 & 4.0 & 5.1 & \multirow{2}{*}{$192.47^{* * *}$} \\
\hline & $b / c$ & C & d & $\mathrm{b}$ & a & \\
\hline
\end{tabular}

${ }^{* * *} p<0.001 ;$ Scheffé ${ }^{\text {ab }}$, post hoc analysis after ANOVA, a $>b>c>d$; ANOVA, analysis of variances. 
'사교적인 스타일'이 가장 활동적이고 그 다음은 '세련된 스타일' 이었으며, '차분한 스타일', '보수적인 스타일', '부드러운 스타일' 은 활동적이지 않은 것으로 나타났다. 개성요인에서는 '사교적인 스타일'이 가장 개성적으로, 그 다음은 '세련된 스타일'이었으며 보수적인 스타일'은 가장 개성적이지 않은 것으로 나타났다.

실버세대 여성유명인 유형에 대한 이미지 어휘의 평가 차이를 살펴본 결과 모든 이미지 어휘에서 유의한 차이가 나타났다. 구 체적으로 살펴보면, '부드러운 스타일'은 전원적인, 따뜻한, 부 드러운, 온순한, 인상 좋은, 수수한의 이미지가 두드러졌으며, 차분한 스타일'은 차분한, 우아한, 매력적인 이미지가, '보수적
인 스타일'은 보수적인, 차분한, 딱딱한, 답답한 이미지가, '세련 된 스타일'은 우아한, 세련된, 도시적인, 매력적인, 차가운, 강 한, 카리스마 있는, 당당한, 화려한 이미지가, '사교적인 스타일' 은 개방적인, 발랄한, 개성 있는, 밝은, 시원한, 사교적인, 들뜬 이미지가 두드러졌다.

\section{4. 실버세대 여성 유명인의 선호도 및 이미지 순위}

20 대가 선호하는 실버세대 여성유명인 50 인을 평점 상위 5 인 과 하위 5 인으로 살펴본 결과는 Table 5 와 같다. 최하정이 평균 5.6점(7점 척도)으로 가장 선호하는 여성유명인으로 나타났으 며, 그 다음은 김미숙(5.5), 서정희(5.3), 장미희(5.2) 순으로 나

Table 4. Difference in adjective according to style group

\begin{tabular}{|c|c|c|c|c|c|c|}
\hline Adjective & Soft style & Calm style & Conservative style & Refined style & Sociable style & $F$-value \\
\hline \multirow{2}{*}{ Elegant-Unelegant } & 4.1 & 5.3 & 4.5 & 5.4 & 3.9 & \multirow{2}{*}{$126.17^{* * *}$} \\
\hline & c & a & $b$ & a & c & \\
\hline \multirow{2}{*}{ Chic-Unchic } & 3.8 & 5.3 & 4.5 & 5.6 & 4.0 & \multirow{2}{*}{$156.13^{* * *}$} \\
\hline & $d$ & b & c & a & $d$ & \\
\hline \multirow{2}{*}{ Urban-Countrified } & 3.6 & 5.2 & 4.7 & 5.7 & 4.2 & \multirow{2}{*}{$166.87^{* * *}$} \\
\hline & $\mathrm{e}$ & $\mathrm{b}$ & c & $\mathrm{a}$ & $d$ & \\
\hline \multirow{2}{*}{ Intellectual-Non-intellectual } & 4.7 & 5.1 & 4.7 & 5.3 & 3.8 & \multirow{2}{*}{$78.74^{* * *}$} \\
\hline & $c$ & $a / b$ & $b$ & a & $d$ & \\
\hline \multirow{2}{*}{ Attractive-Unattractive } & 4.2 & 5.0 & 3.9 & 5.1 & 4.7 & \multirow{2}{*}{$52.26^{* * *}$} \\
\hline & c & $a / b$ & $d$ & a & $b$ & \\
\hline \multirow{2}{*}{ Warm-Cool } & 5.2 & 4.5 & 3.5 & 3.2 & 4.5 & \multirow{2}{*}{$139.85^{* * *}$} \\
\hline & a & b & c & c & b & \\
\hline \multirow{2}{*}{ Open-minded-Conservative } & 4.0 & 4.0 & 3.1 & 4.1 & 5.1 & \multirow{2}{*}{$90.18^{* * *}$} \\
\hline & $\mathrm{b}$ & $\mathrm{b}$ & c & $\mathrm{b}$ & a & \\
\hline \multirow{2}{*}{ Strong-Weak } & 4.1 & 4.6 & 5.2 & 5.6 & 5.5 & \multirow{2}{*}{$114.56^{* *}$} \\
\hline & $d$ & c & $\mathrm{b}$ & a & a & \\
\hline \multirow{2}{*}{ Charismatic-Uncharismatic } & 4.0 & 4.8 & 5.2 & 5.8 & 5.4 & \multirow{2}{*}{$119.00^{* * *}$} \\
\hline & $d$ & c & $b$ & a & $b$ & \\
\hline \multirow{2}{*}{ Lively-Quiet } & 4.3 & 3.8 & 2.9 & 3.4 & 4.9 & \multirow{2}{*}{$105.94^{* * *}$} \\
\hline & $\mathrm{b}$ & c & $\mathrm{e}$ & $d$ & a & \\
\hline \multirow{2}{*}{ Soft-Hard } & 5.0 & 4.5 & 3.2 & 3.3 & 4.3 & \multirow{2}{*}{$99.72^{* * *}$} \\
\hline & a & $\mathrm{b}$ & c & c & $b$ & \\
\hline \multirow{2}{*}{ Intellectual-Non-intellectual } & 4.3 & 4.3 & 3.8 & 5.1 & 5.8 & \multirow{2}{*}{$113.74^{* * *}$} \\
\hline & $c$ & c & $d$ & $b$ & a & \\
\hline \multirow{2}{*}{ Bright-Dark } & 5.2 & 4.6 & 3.7 & 4.1 & 5.3 & $10764^{* * *}$ \\
\hline & a & $\mathrm{b}$ & $d$ & $\mathrm{c}$ & a & 107.64 \\
\hline Adantable-_lnadantable & 4.6 & 4.5 & 4.0 & 5.0 & 5.5 & $6463^{* * *}$ \\
\hline Adaptable-Unadaptable & $\mathrm{c}$ & c & $d$ & $\mathrm{~b}$ & a & 64.63 \\
\hline & 4.9 & 5.1 & 5.1 & 5.8 & 5.8 & $6088^{* * *}$ \\
\hline Dignified-Undignified & $\mathrm{b}$ & $\mathrm{b}$ & $\mathrm{b}$ & a & a & 60.88 \\
\hline Docile-Dread & 4.6 & 4.3 & 3.3 & 3.0 & 3.7 & $11568^{* * *}$ \\
\hline Doclle-dread & a & $\mathrm{b}$ & $d$ & d & c & 115.08 \\
\hline Good impression-Bad & 5.1 & 5.0 & 3.9 & 4.0 & 4.7 & $8194^{* * *}$ \\
\hline impression & a & a & c & c & $b$ & 81.94 \\
\hline Modect-forropus & 4.7 & 4.2 & 4.0 & 2.9 & 3.0 & $14075^{* * *}$ \\
\hline IVIodest-Gorgeous & a & b & $b$ & c & c & 140.15 \\
\hline Sociable-Unsociable & 5.0 & 4.7 & 4.2 & 4.7 & 5.4 & $4400^{* * *}$ \\
\hline Sociable-Unsociable & $\mathrm{b}$ & $\mathrm{b}$ & c & $\mathrm{b}$ & $a$ & \\
\hline Excited-Calm & 3.6 & 3.0 & 3.1 & 3.4 & 4.9 & $117.59^{* * *}$ \\
\hline & $\mathrm{b}$ & c & c & $\mathrm{b}$ & $\mathrm{a}$ & \\
\hline
\end{tabular}

${ }^{* * *} p<0.001$, Scheffé $^{\mathrm{ab}}$, post hoc analysis after ANOVA, $a>b>c>d$; ANOVA, analysis of variances. 
타났다. 선호하지 않는 여성유명인은 김부선이 평균 3.2 점으로 가장 낮은 점수이며, 그 다음은 추미애(3.3), 최진희(3.4), 홍여 진(3.5), 이보희(3.5) 순으로 나타났다.

실버세대 여성유명인에 대해 이미지 구성요인별 해당 어휘의 평점을 구하고, 상위 5 인과 하위 5 인의 순위를 살펴본 결과, 원 미경(5.8), 이성미(5.6), 양희경(5.5), 김혜정(5.2), 김미경(5.0) 순으로 친화성이 높았으며 이혜영(2.8), 이보희(3.0), 이미숙 (3.1) 순으로 친화성이 낮게 나타났다. 매력성 요인에서는 장미 희(6.3), 이미숙(5.9), 김미숙(5.9), 정애리(5.8) 순으로 점수가 높았고, 김연자(3.0), 양희경(3.5) 등의 유명인이 낮은 점수를 나타냈다. 활동성요인에서는 인순이(6.2), 이미숙(6.0), 김연자 (5.7), 최하정(5.7) 순으로 점수가 높았으며 서정희(4.0), 이성미 (4.2), 원미경(4.2), 진미령(4.2)이 활동성이 낮게 나타났다. 또 한 김연자(5.6), 최하정(5.5), 인순이(5.3), 현숙(5.2) 순으로 개
성적인 점수가 높았고, 추미애(2.5), 박영선(2.8), 원미경(3.1) 순으로 점수가 낮게 나타났다.

\section{Conclusion}

이 연구의 결과를 요약하고 결론을 내리면 다음과 같다.

첫째, 실버세대 여성유명인의 이미지 구성요인은 친화성, 매 력성, 활동성, 개성의 4 요인으로 명명하였으며 전체 변량의 $65.28 \%$ 를 차지하였다. 이 중 친화성 요인이 제 1 요인으로 나타 나 실버세대 여성유명인의 이미지를 나타내는 가장 중요한 차원 임을 알 수 있었다.

둘째, 실버세대 여성유명인을 이미지에 따라 유형화한 결과 5 개의 군집으로 나누어졌으며 1 군집은 이성미, 양희경, 원미경

Table 5. Preference and image ranking

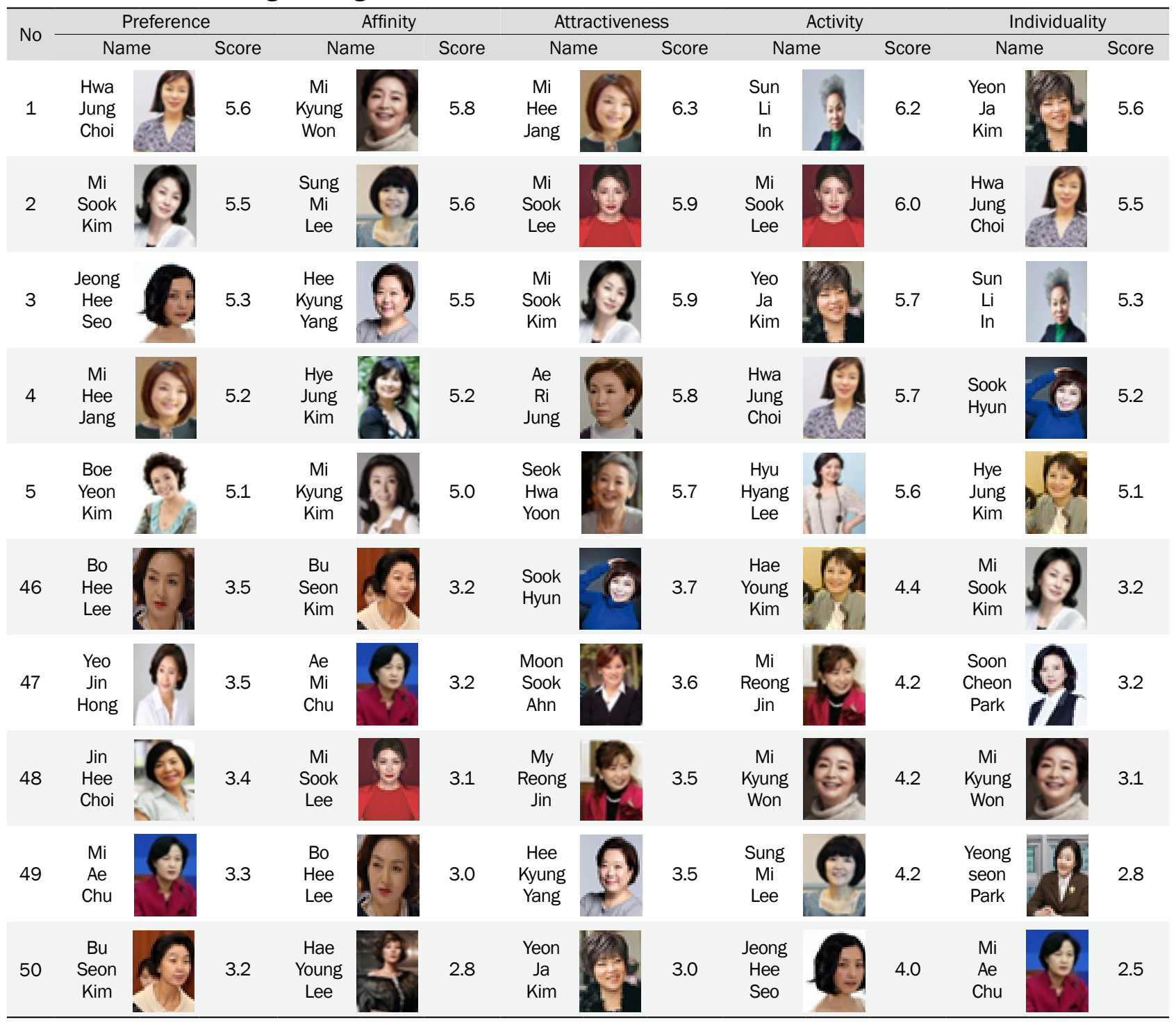


등 10 명으로 구성되어 '부드러운 스타일'로 명명하였으며 2 군집 은 김미숙, 최명길, 오미희 등 13 명으로 구성되어 '차분한 스타 일'로, 3 군집은 박영선, 추미애 등 7명으로 '보수적인 스타일'로, 4 군집은 장미희, 이미숙, 황신혜 등 11 명으로 '세련된 스타일' 로, 5 군집은 노사연, 최하정, 안문숙 등 9 명으로 '사교적인 스타 일'로 명명하였다. 각각의 군집은 미용스타일에 차이가 있었으며 분석된 특징을 참고하여 추구하는 스타일 연출과 이미지 구현에 활용해볼 수 있을 것이다.

셋째, 실버세대 여성유명인의 유형에 따른 이미지 차이를 살펴 본 결과 부드러운 스타일은 가장 친화성이 높았으며 '차분한 스 타일'과 '세련된 스타일'은 매력성이 두드러지고 사교적인 스타일 은 활동성과 개성이 가장 높게 평가되었다. 따라서 친화적인 이 미지로 평가 받고자 할 경우에는 '부드러운 스타일'로 연출하고, 매력적인 이미지를 나타내고자 한다면 '차분한 스타일'과 '세련된 스타일'의 외형적 특징을 참고로 연출해 볼 수 있을 것이다. 활동 적이며 개성이 뚜렷한 이미지를 고려한다면 '사교적인 스타일'로 연출하는 것이 효과적일 것이다.

넷째, 20 대가 선호하는 실버세대 여성유명인의 순위를 알아본 결과 최하정, 김미숙 순으로 이들의 이미지는 매력적이고 개성이 두드러졌으며 선호도가 낮은 유명인은 김부선, 추미애 등으로 이 들은 친화성이 낮게 나타났다. 이와 같은 결과는 20 대의 선호도 를 고려한 이미지 메이킹 전략에 활용해 볼 수 있을 것이다.

이 연구는 평가 대상자가 20 대로 한정되었고 지역적 제한이 따르므로 확대 해석에 주의가 필요하다. 추후 연령에 따른 평가 차이를 분석하거나 남자유명인을 대상자로 한 후속연구를 해볼 수 있을 것이다.

\section{Acknowledgements}

이 논문은 2017학년도 창신대학교 교내연구비에 의해 연구되 었음(과제번호: 창신 2017-교내-50).

\section{References}

Im JM, O IY. A study on old aged women's appearance concern and behavior of appearance care. Journal of the Korean Society of Cosmetology, 16: 475-486, 2010.

Jo SY, Kim JD. A study on the attitude and purchase behaviors for silver generation toward makeup and cosmetics. Journal of the Korean Society of Cosmetology, 15: 1477-1492, 2009.

Kang EM, Park EJ. Effects of service quality on consumer satisfaction and repurchase intention of apparel products and hairdressing services for silver consumers. Journal of the Korean Society of Clothing and Textiles, 31: 584-593, 2007.

Kim AK, Lee KH. A study on the facial color \& shape of an elderly women. Fashion \& Textile Research Journal, 11: 103-111, 2009.

Kim AK, Lee KH. A study regarding head image's through fashion collection. Journal of the Korean Society of Clothing and Textiles, 27: 904-912, 2003.

Kim MH, Yoo YJ, Chon HJ. A study on make-up interest and cosmetic usage of silver generation women. Asian Journal of Beauty and Cosmetology, 11: 983-991, 2013.

Kim YK, Kang KJ. The effect of clothing style and color, tone combination on impressions formation. Journal of the Korean Society of Clothing and Textiles, 27: 395-406, 2003.

Kim JK. A study on senior human rights in an aging society. Journal of Social Welfare Management, 1: 1-18, 2014.

Kim JS. A study on the relationship of the state of skin care to self-esteem and self-efficacy in elderly women. Asian Journal of Beauty and Cosmetology, 9: 127-140, 2011.

Lee HH, Park CB. Effects of clothing cues and perceiver's personality traits variables on impression formation. Journal of the Korean Society of Clothing and Textiles, 22: 341-352, 1998.

Oh YK, Lee KH. A study on the type analysis and image of the personal style: focused on Korean female entertainers. Journal of the Korean Society of Clothing and Textiles, 30: 137-145, 2006.

Park SM. The influence on self-esteem for skin \& health care behavior according to the lifestyle of new sliver generation. Asian Journal of Beauty and Cosmetology, 13: 123-133, 2015.

Sim JH. A study on clothing image evaluation and preference according to self-image classification of the middle-aged women. Journal of the Korean Society of Clothing and Textiles, 30: 1608-1617, 2006.

Wee HJ, Sohn HS. A study on self-image of the eldery women. Journal of Fashion Business, 5: 117-127, 2001. 


\section{국문초록}

\section{실버세대 여성유명인의 이미지 유형화 및 미용스타일 분석}

오윤경

창신대학교 미용예술학과, 경상남도 창원시, 한국

목적: 본 연구는 실버세대 여성유명인을 대상으로 젊은 세대가 느끼는 이미지에 따라 유형화하고 유형에 따른 미용스타일과 이미지 차이를 분석하고자 한다. 이러한 연구는 새로운 소비계층으로 부각되고 있는 실버세대의 대표적인 스타일을 구분함으로써 실버세 대 여성에 대한 이해를 돕고 패션과 미용 상품 개발 및 이미지메이킹의 기초자료로 활용될 수 있을 것이다. 방법: 실버세대 여성유 명인을 55 세 이상 65 세 이하를 대상으로 50 명을 선정하였으며, 이미지 평가를 위하여 선행연구를 참고로 총 20 개의 형용사쌍을 추 출하였고 7점 의미미분척도로 구성하였다. 여성유명인의 선호도 평가는 '좋아하는-좋아하지 않는' 문항을 사용하였고 자료 수집은 2018년 6월 1일부터 6월 15일까지 이미지 평가를 실시하여 분석하였다. 결과: 첫째, 실버세대 여성유명인의 이미지 구성요인은 친 화성, 매력성, 활동성, 개성의 4 개 요인으로 명명하였으며 전체 변량의 $65.28 \%$ 를 차지하였다. 둘째, 실버세대 여성유명인의 군집은 5 개로 나타났으며 '부드러운 스타일', '차분한 스타일', '보수적인 스타일', '세련된 스타일', '사교적인 스타일'로 명명하였다. 셋째, 실 버세대 여성유명인의 유형에 따른 이미지 차이를 살펴본 결과, '부드러운 스타일'은 가장 친화성이 높았으며 '차분한 스타일'과 '세련 된 스타일'은 매력성이 두드러지고 '사교적인 스타일'은 활동성과 개성이 가장 높게 평가되었다. 넷째, 20 대가 선호하는 실버세대 여 성유명인의 순위를 알아본 결과, 최하정, 김미숙 순으로 이들의 이미지는 매력적이고 개성이 두드러졌으며 선호도가 낮은 유명인은 김부선, 추미애 등으로 이들은 친화성이 낮게 나타났다. 결론: 실버세대 여성유명인의 이미지는 가장 중요한 차원으로 친화성 요인 임을 알 수 있으며, 군집에 따른 미용스타일의 분석된 특징을 참고하여, 추구하는 스타일 연출 및 이미지 구현에 활용해볼 수 있을 것이다. 또한, 친화적인 이미지로 평가 받고자 할 경우에는 '부드러운 스타일'로 연출하고, 매력적인 이미지를 나타내고자 한다면 '차 분한 스타일'과 '세련된 스타일'의 외형적 특징을 참고로 연출해 볼 수 있을 것이다. 활동적이며 개성이 뚜렷한 이미지를 고려한다면 '사교적인 스타일'로 연출하는 것이 효과적일 것이다.

핵심어: 실버세대, 유명인, 유형화, 이미지, 미용스타일

이 논문은 2017학년도 창신대학교 교내연구비에 의해 연구되었음(과제번호: 창신 2017-교내-50).

\section{참고문헌}

강은미, 박은주. 의류제품과 미용서비스 구매 시 점포서비스품질이 실버소비자 만족 및 재구매의도에 미치는 영향. 한국의 류학회지, 31: 584-593, 2007.

김미희, 유유정, 전해정. 실버세대 여성들의 화장관심도와 화장품 사용에 관한 연구. 아시안뷰티화장품학술지, $11: 983-$ $991,2013$.

김애경, 이경희. 패션컬렉션에 나타난 Head Image 연구. 한국의류학회지, 27: 904-912, 2003.

김애경, 이경희. 노인여성 얼굴색과 얼굴 형태 분석. 한국의류산업학회지, 11: 103-111, 2009.

김윤경, 강경자. 의복스타일과 색상·톤조합이 인상형성에 미치는 영향. 한국의류학회지, 27: 395-406, 2003.

김재경. 현대사회에 노인문제와 노인인권에 관한 고찰. 사회복지경영연구, 1: 1-18, 2014.

김정숙. 노년여성의 피부관리 실태에 따른 자아존중감과 자기효능감에 관한 연구. 아시안뷰티화장품학술지, 9: 127-140, 2015.

박선민. 뉴 실버세대의 라이프스타일에 따른 피부미용건강관리행동이 자아존중감에 미치는 영향. 아시안뷰티화장품학술 지, 13: 123-133, 2015. 
심정희, 중년 여성의 자기 이미지 유형화에 따른 의복 이미지 평가와 선호. 한국의류학회지, 30: 1608-1617, 2006.

오윤경, 이경희. 퍼스널 스타일의 유형 분석과 이미지 연구: 국내여자연예인을 중심으로. 한국의류학회지, 30: 137-145, 2006.

이현화, 박찬부. 지각자의 성격변인에 따른 의복단서의 인상효과에 대한 연구. 한국의류학회지, 22: 341-352, 1998.

임정미, 오인영. 노년기 여성의 외모관심도와 외모관리행동 연구. 한국미용학회지, 16: 475-486, 2010.

위혜정, 손희순. 노년 여성의 자아이미지에 관한 연구. 패션 비즈니스, 5: 117-127, 2001.

조선영, 김주덕. 실버세대 여성들의 화장에 대한 태도와 화장품 구매행동에 관한 연구. 한국미용학회지, 15: 1477-1492, 2009. 


\section{中文摘要}

\section{银发一族女性名人的形象分类和美容风格分析}

吳允京

昌信大学美容艺术学科, 庆尚南道昌原市, 韩国

目的：根据年轻一代的形象对银发一族女性名人进行分类，以便根据世代类型分析美容，风格和形象差异。该 研究数据可用于通过提高我们对银代女性代表风格的理解来为时尚和美容产品的发展提供信息, 该风格正在成 为新的消费群体。方法: 选定银发一族年龄从 55 岁到 65 岁之间的女性名人的 50 张照片。为评价形象参考先行研 究提取 20 个形容词对, 并由 7点语义差分异量表组成。女性名人的偏好评价为“喜欢-不喜欢’。数据收集于 2018 年6月1日至2018年6月15日进行。结果：该研究的结果总结如下。首先，有四个因素构成银代女性名人的形象 亲和力, 吸引力, 活动和个性-占总变异的 $65.28 \%$ 。其次, 银代女性名人被分为五个群体之一, 分别名为“软风 格”, “冷静风格”, “保守风格”, “精致风格”, “社会风格”。第三, 由于审查了 根据类型的图像差异, “柔和风格” 具有最高的亲和力, “冷静风格”和“精致风格”被评为更具吸引力, “社交风格”具有最高的活动性和个性评级。第 四, 被二十几岁的人认为最具吸引力和独特的银代女性名人的形象是崔华贞和金美淑的形象。结论: 银发一族 女性名人形象最重要的维度是亲和力因素, 可以应用于追求风格呈现和图像实现, 参照社区定义的美和风格特 征。因此，这项研究发现友好形象的特点是“柔和的风格”; 具有“平静风格”和或“精致风格”的外在特征的迷人形象; 具有个性的积极形象以“社会风格’为特征。

关键词: 银发一族, 名人，类型化，形象，美容设计 